\title{
Flavobacterium cheniae sp. nov., isolated from sediment of a eutrophic reservoir
}

\author{
Correspondence \\ Hong-Li Yuan \\ hlyuan@cau.edu.cn
}

\author{
Jian-Hang Qu, Hai-Feng Li, Jin-Shui Yang and Hong-Li Yuan \\ College of Biological Sciences, Key Laboratory of Agro-Microbial Resource and Application, \\ Ministry of Agriculture, China Agricultural University, Beijing 100094, PR China
}

\begin{abstract}
A Gram-negative, rod-shaped, yellow pigmented bacterium, strain $\mathrm{NJ}-26^{\top}$, was isolated from sediment of the eutrophicated Guanting Reservoir in Beijing, China. A phylogenetic analysis based on $16 \mathrm{~S}$ rRNA gene sequences placed strain $\mathrm{NJ}-26^{\top}$ within the genus Flavobacterium in the family Flavobacteriaceae. The highest sequence similarity was found with Flavobacterium cucumis R2A45-3 $3^{\top}(97.7 \%)$. The major fatty acids $(>5 \%)$ of the isolate were iso- $\mathrm{C}_{15: 0 \text {, iso- }}$ $\mathrm{C}_{17: 1} \omega 9 c, \mathrm{C}_{15: 0}$, iso- $\mathrm{C}_{17: 0} 3-\mathrm{OH}$, iso- $\mathrm{C}_{15: 1} \mathrm{G}$ and iso- $\mathrm{C}_{15: 0} 3-\mathrm{OH}$. The $\mathrm{G}+\mathrm{C}$ content of the genomic DNA was 40.6 mol\%. The DNA-DNA relatedness value with $F$. cucumis R2A45- $3^{\top}$ was $5.4 \%$. Molecular and phenotypic data suggest that strain $\mathrm{NJ}-26^{\top}$ represents a novel species within the genus Flavobacterium, for which the name Flavobacterium cheniae sp. nov. is proposed. The type strain is NJ-26 ${ }^{\top}\left(=\right.$ CGMCC $1.6844^{\top}=$ NBRC $\left.103934^{\top}\right)$.
\end{abstract}

The genus Flavobacterium, belonging to the phylum Bacteroidetes (formerly the Cytophaga-FlavobacteriumBacteroides group), was proposed by Bergey et al. (1923) and its description was considerably emended by Bernardet et al. (1996). Flavobacterium species have been isolated from a wide range of habitats (sediment, fresh water, seawater, soil, micromats, etc.) and display a variety of physiological characteristics (Bernardet \& Bowman, 2006). Recently described species are Flavobacterium defluvii, F. aquidurense, $F$. hercynium, $F$. terrigena, $F$. terrae and $F$. cucumis (Park et al., 2007; Cousin et al., 2007; Yoon et al., 2007; Weon et al., 2007). In the present study, a novel species is proposed following the polyphasic taxonomy study of a sediment isolate.

A sediment sample was collected in July 2006 from the eutrophicated Guanting Reservoir in Beijing city, China. Characteristics of the sample were: $\mathrm{pH} 7.7,276.54 \mathrm{mg}$ microbial biomass carbon $\mathrm{kg}^{-1}, 3.92 \%$ organic carbon, $0.48 \%$ total nitrogen, $0.04 \%$ available $\mathrm{K}$ and $8.2 \mathrm{mg}$ available $\mathrm{P} \mathrm{kg}^{-1}$.

For isolation, the sediment sample was suspended in sterilized water, serially diluted and spread on plates of sediment steep medium prepared as follows: $400 \mathrm{~g}$ sediment was boiled in 11 distilled water for $10 \mathrm{~min}$ and then $0.5 \mathrm{~g}$ peptone, $0.5 \mathrm{~g}$ yeast extract and $15 \mathrm{~g}$ agar were added to $1 \mathrm{l}$ supernatant; the $\mathrm{pH}$ was not adjusted. Plates were incubated at $28{ }^{\circ} \mathrm{C}$ for 10 days. A single colony of

The GenBank/EMBL/DDBJ accession number for the $16 \mathrm{~S}$ rRNA gene sequence of strain $\mathrm{NJ}-26^{\top}$ is EF407880.

Maximum-parsimony and minimum-evolution phylogenetic trees based on $16 \mathrm{~S}$ rRNA gene sequences are available as supplementary material with the online version of this paper. strain $\mathrm{NJ}-26^{\mathrm{T}}$ was picked and routinely subcultured on modified R2A medium (yeast extract, $0.5 \mathrm{~g}$; polypeptone, $0.5 \mathrm{~g}$; Casamino acids, $0.5 \mathrm{~g}$; glucose, $0.5 \mathrm{~g}$; soluble starch, $0.5 \mathrm{~g} ; \mathrm{K}_{2} \mathrm{HPO}_{4}, 0.3 \mathrm{~g} ; \mathrm{MgSO}_{4} \cdot 7 \mathrm{H}_{2} \mathrm{O}, 0.05 \mathrm{~g}$; distilled water 1 l; $\mathrm{pH} 7.2$ ).

The $16 \mathrm{~S}$ rRNA gene of strain NJ-26 ${ }^{\mathrm{T}}$ was amplified by PCR using the universal bacterial primers 27F and 1495R (Ying

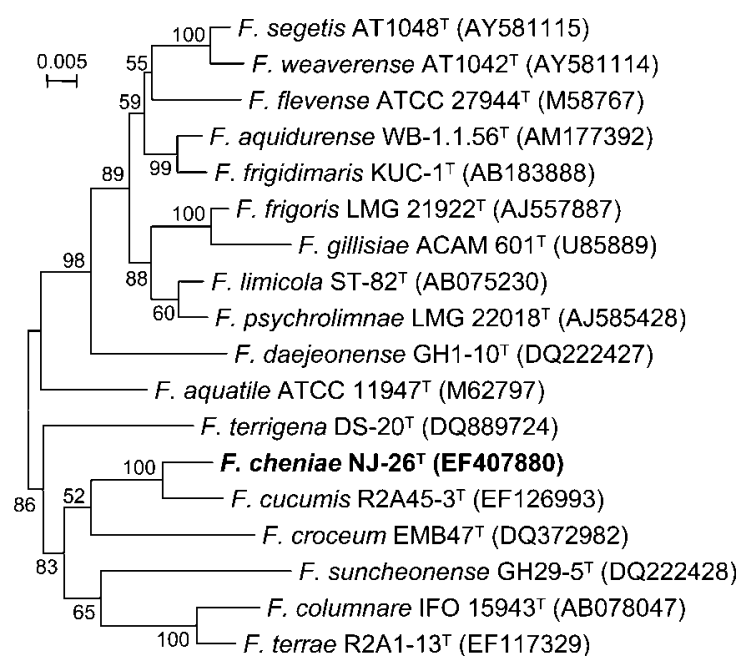

Fig. 1. Neighbour-joining tree based on the 16S rRNA gene sequences of strain $\mathrm{NJ}-26^{\top}$ and members of closely related Flavobacterium species. Numbers at nodes are bootstrap percentages $>50 \%$ from 1000 replicates. Bar, 0.005 substitutions per nucleotide position. Minimum-evolution and maximum-parsimony trees are shown in Supplementary Fig. S1. 
et al., 2007) and the $1410 \mathrm{bp}$ amplified fragment was sequenced with an ABI 3730 XL 96-capillary sequencer (Applied Biosystems). The search for phylogenetic neighbours and calculation of pairwise 16S rRNA gene sequence similarity were achieved using the EzTaxon server (http:// www.eztaxon.org/; Chun et al., 2007). Phylogenetic trees were constructed by using the neighbour-joining, maximum-parsimony and minimum-evolution algorithms available in MEGA version 3.1 (Kumar et al., 2004) after multiple alignment of the data by CLUSTAL $\mathrm{w}$ (Thompson et al., 1994). The topology of the tree was evaluated by using Kimura's two-parameter calculation model (Kumar et al., 2004) based on 1000 replicates. In the neighbour-joining phylogenetic tree (Fig. 1), the isolate was located within the genus Flavobacterium, sharing $97.7 \%$ 16S rRNA sequence similarity with $F$. cucumis $\mathrm{R} 2 \mathrm{~A} 45-3^{\mathrm{T}}$ (Weon et al., 2007) (bootstrap value $100 \%$ ). It was also closely related to $F$. croceum EMB $47^{\mathrm{T}}$ (Park et al., 2006), F. suncheonense DSM $17707^{\mathrm{T}}$ (Kim et al., 2006), F. columnare IFO $15943^{\mathrm{T}}$ (Bernardet et al., 1996), F. terrae R2A1-13 ${ }^{\mathrm{T}}$ (Weon et al., 2007), F. terrigena DS $-20^{\mathrm{T}}$ (Yoon et al., 2007) and F. aquatile ATCC $11947^{\mathrm{T}}$ (Bernardet et al., 1996), with sequence similarities of $93.7-95.1 \%$. The same general topology was found in the maximum-parsimony and minimum-evolution phylogenetic trees, available as Supplementary Fig. S1 in IJSEM Online.

Growth at 4, 18, 22, 28, 32, 37 and $50{ }^{\circ} \mathrm{C}$ and $\mathrm{pH} 5,5.5$, $6.0,6.5,7.0,7.5,8.0$ and 8.5 was assessed after 10 days of incubation. The $\mathrm{pH}$ of $\mathrm{R} 2 \mathrm{~A}$ broth was adjusted by adding $1 \mathrm{M} \mathrm{NaOH}$ or $1 \mathrm{M} \mathrm{HCl}$. Tolerance to salinity was tested in R2A broth supplemented with $0-5.0 \% \mathrm{NaCl}(\mathrm{w} / \mathrm{v})$ at $1 \%$ intervals after 10 days of incubation. Growth on nutrient agar (NA), trypticase soy agar (TSA), marine agar 2216 (MA) and PYG agar was also evaluated at $28{ }^{\circ} \mathrm{C}$ for 10 days. All media were prepared in the laboratory following the composition of Difco media (NA, TSA and MA) or according to Zhu et al. (2003) (PYG). Flexirubintype pigments were sought by flooding a small mass of bacterial cells with $20 \% \mathrm{KOH}$ according to Bernardet et al. (2002). Motility was investigated using a fresh R2A broth culture using the hanging drop technique. Hydrolysis of

Table 1. Differential characteristics of strain $\mathrm{NJ}-26^{\top}$ and related Flavobacterium species

Taxa: 1, strain NJ-26 ${ }^{\mathrm{T}}$ (Flavobacterium cheniae sp. nov.); 2, F. cucumis R2A45-3 ${ }^{\mathrm{T}}$ (data from Weon et al., 2007); 3, F. croceum EMB47 ${ }^{\mathrm{T}}$ (Park et al., 2006); 4, F. suncheonense DSM 17707 ${ }^{\mathrm{T}}$ (Kim et al., 2006); 5, F. columnare IFO 15943 ${ }^{\mathrm{T}}$ (Bernardet \& Grimont, 1989; Bernardet et al., 1996); 6, F. terrae R2A1-13 ${ }^{\mathrm{T}}$ (Weon et al., 2007); 7, F. terrigena DS-20 (Yoon et al., 2007); 8, F. aquatile (Bernardet et al., 1996). +, Positive; -, negative; w, weakly positive; NR, not reported; $v$, variable among references. All strains are positive for oxidase activity and gelatin degradation. All strains tested are negative for degradation of $\mathrm{CM}$-cellulose, chitin and urea, reduction of nitrate and $\beta$-galactosidase activity.

\begin{tabular}{|c|c|c|c|c|c|c|c|c|}
\hline Characteristic & 1 & 2 & 3 & 4 & 5 & 6 & 7 & 8 \\
\hline Colony pigmentation ${ }^{\star}$ & Y & Y & Y & Y & GY & YO & DY & $\mathrm{CY}$ \\
\hline \multicolumn{9}{|l|}{ Growth on: } \\
\hline TSA & $\mathrm{W}$ & $\mathrm{w}$ & $\mathrm{w}$ & $\mathrm{W}$ & - & $\mathrm{w}$ & - & + \\
\hline Growth at $37^{\circ} \mathrm{C}$ & - & + & + & + & - & + & - & + \\
\hline \multicolumn{9}{|l|}{$\mathrm{pH}$ for growth } \\
\hline Optimum & 7.5 & 7.0 & $7.5-8.0$ & NR & NR & 7.0 & $6.5-7.0$ & $\mathrm{NR}$ \\
\hline \multicolumn{9}{|l|}{$\mathrm{NaCl}$ concentration for growth (\%) } \\
\hline Range & $0-0.8$ & $0-2.0$ & $0-1.0$ & $0-1.0$ & $0-0.5$ & $0-2.0$ & NR & $<0.5$ \\
\hline Optimum & 0 & $0-2.0$ & 0 & $\mathrm{NR}$ & 0 & $0-2.0$ & NR & 0 \\
\hline Catalase activity & + & + & - & + & + & - & + & + \\
\hline Flexirubin reaction & - & - & - & - & + & + & + & - \\
\hline Starch & $\mathrm{W}$ & + & - & - & - & + & - & $\mathrm{V}$ \\
\hline Casein & - & + & + & + & + & + & + & + \\
\hline Tyrosine & + & + & - & + & - & - & + & $\mathrm{V}$ \\
\hline DNA & - & - & NR & - & + & - & - & - \\
\hline $\mathrm{H}_{2} \mathrm{~S}$ production & $\mathrm{w}$ & NR & - & NR & + & NR & - & - \\
\hline Brown pigment on tyrosine agar & + & NR & NR & NR & - & NR & NR & - \\
\hline Precipitation on egg-yolk agar & + & NR & NR & + & + & NR & NR & + \\
\hline DNA G $+C$ content $(\mathrm{mol} \%)$ & 40.6 & 38 & 40.8 & 39 & 32 & 34 & 38.2 & 33 \\
\hline
\end{tabular}

${ }^{\star} \mathrm{CY}$, Cream-yellow; DY, dark yellow; GY, greenish yellow; Y, yellow; YO, yellowish orange. 
pectin, chitin, Tween 80 , CM-cellulose, casein, DNA and urea was investigated as described by Park et al. (2006) or Dong \& Cai (2001). Utilization of carbon and energy sources was investigated in a basal medium containing $\left(\mathrm{l}^{-1}\right) 1 \mathrm{~g}\left(\mathrm{NH}_{4}\right)_{2} \mathrm{HPO}_{4}, 0.1 \mathrm{~g}$ yeast extract, $0.3 \mathrm{~g} \mathrm{~K}_{2} \mathrm{HPO}_{4}$, $0.05 \mathrm{~g} \mathrm{MgSO}_{4} \cdot 7 \mathrm{H}_{2} \mathrm{O}, \mathrm{pH}$ 7.2. Carbon substrates were added at a concentration of $0.5 \%(\mathrm{w} / \mathrm{v})$. The following biochemical and physiological tests were performed according to Dong \& Cai (2001) or Kim et al. (2006): oxidase and catalase activities, formation of a precipitate on egg-yolk agar, production of acid from carbohydrates, hydrolysis of tyrosine and production of a brown pigment on tyrosine agar, glucose utilization, nitrate reduction, production of $\mathrm{H}_{2} \mathrm{~S}$, alkaline phosphatase, lipase, $\beta$ galactosidase, urease, tryptophan deaminase and arginine dihydrolase activities and hydrolysis of gelatin, starch and $o$-nitrophenyl $\beta$-D-galactopyranoside (ONPG).

The phenotypic characteristics of strain $\mathrm{NJ}-26^{\mathrm{T}}$ are given in Table 1 and in the species description. Strain NJ-26 could be distinguished from its closest phylogenetic neighbour, F. cucumis $\mathrm{R} 2 \mathrm{~A} 45-3^{\mathrm{T}}$, by the hydrolysis of casein, ranges of temperature and $\mathrm{pH}$ for growth, tolerance to $\mathrm{NaCl}$ and optimum $\mathrm{NaCl}$ concentration.

Cells grown on R2A agar for 2 days at $28{ }^{\circ} \mathrm{C}$ were used for cellular fatty acid analysis. Fatty acid methyl esters were prepared and identified using the Sherlock Microbial Identification System (MIDI). The major cellular fatty acids $(>5 \%)$ of strain $\mathrm{NJ}-26^{\mathrm{T}}$ were iso- $\mathrm{C}_{15: 0}$, iso$\mathrm{C}_{17: 1} \omega 9 c, \mathrm{C}_{15: 0}$, iso- $\mathrm{C}_{17: 0} 3-\mathrm{OH}$, iso- $\mathrm{C}_{15: 1} \mathrm{G}$ and iso$\mathrm{C}_{15: 0} 3-\mathrm{OH}$. The proportion of several fatty acids clearly distinguished strain $\mathrm{NJ}-26^{\mathrm{T}}$ from F. cucumis $\mathrm{R} 2 \mathrm{~A} 45-3^{\mathrm{T}}$ (Table 2). However, these discrepancies may result partly from the use of different culture conditions.

Genomic DNA was extracted according to Marmur (1961) and Johnson (1985a, b) from cells cultured for 2 days in R2A broth. The $\mathrm{G}+\mathrm{C}$ content of the DNA was determined by thermal denaturation (De Ley, 1970) using DNA from Escherichia coli K-12 as a control. The DNA G + C content

Table 2. Cellular fatty acid compositions of strain $\mathrm{NJ}-26^{\top}$ and type strains of related Flavobacterium species

Strains: 1, strain NJ-26 ${ }^{\mathrm{T}}$ (F. cheniae sp. nov.); 2, F. cucumis R2A45-3 ${ }^{\mathrm{T}}$ (data from Weon et al., 2007); 3, F. croceum EMB47 ${ }^{\mathrm{T}}$ (Park et al., 2006); 4, F. suncheonense DSM $17707^{\mathrm{T}}$ (Kim et al., 2006); 5, F. columnare IFO 15943 ${ }^{\mathrm{T}}$ (Weon et al., 2007); 6, F. terrae R2A1-13 ${ }^{\mathrm{T}}$ (Weon et al., 2007); 7, F. terrigena DS $-20^{\mathrm{T}}$ (Yoon et al., 2007); 8, F. aquatile DSM $1132^{\mathrm{T}}$ (Weon et al., 2007). Fatty acids amounting to $<1 \%$ in all strains studied are not listed. Some of the strains listed were grown under different culture conditions. tr, Traces $(<1 \%)$.

\begin{tabular}{|c|c|c|c|c|c|c|c|c|}
\hline Fatty acid & 1 & 2 & 3 & 4 & 5 & 6 & 7 & 8 \\
\hline iso- $\mathrm{C}_{13: 0}$ & $\operatorname{tr}$ & & 1.0 & 1.9 & 1.3 & & & \\
\hline iso- $\mathrm{C}_{14: 0}$ & & 5.3 & 8.7 & $\operatorname{tr}$ & 3.8 & 4.7 & & 3.1 \\
\hline iso- $\mathrm{C}_{14: 0} 3-\mathrm{OH}$ & & 1.8 & 2.6 & & 1.5 & 1.1 & & \\
\hline Unknown 13.565 & 1.6 & & & & & & & \\
\hline $\mathrm{C}_{15: 0}$ & 15.4 & & 10.8 & & & 4.3 & & \\
\hline $\mathrm{C}_{15: 0} 2-\mathrm{OH}$ & & & 2.0 & $\operatorname{tr}$ & & & & \\
\hline $\mathrm{C}_{15: 0} 3-\mathrm{OH}$ & 1.4 & 1.5 & 1.3 & $\operatorname{tr}$ & 1.9 & 2.2 & & 2.1 \\
\hline anteiso- $\mathrm{C}_{15: 0}$ & 2.0 & 4.4 & 5.1 & 2.1 & 2.2 & 2.8 & & 3.5 \\
\hline iso- $\mathrm{C}_{15: 0}$ & 27.7 & 17.5 & 9.3 & 29.9 & 30.1 & 18.4 & 30.1 & 17.0 \\
\hline iso- $\mathrm{C}_{15: 0} 3-\mathrm{OH}$ & 6.3 & 5.1 & 5.9 & 11.1 & 5.2 & 6.7 & 6.6 & 6.4 \\
\hline iso- $\mathrm{C}_{15: 1} \mathrm{G}$ & 7.2 & 9.9 & 11.5 & 12.0 & 14.6 & 10.7 & & 7.4 \\
\hline iso- $\mathrm{C}_{15: 1}$ & & & & & & & 9.0 & \\
\hline $\mathrm{C}_{15: 1} \omega 6 c$ & 2.7 & 2.0 & & $\operatorname{tr}$ & & 1.1 & 1.3 & 10.8 \\
\hline anteiso- $\mathrm{C}_{15: 1} \mathrm{~A}$ & & & 1.6 & & & & & \\
\hline $\mathrm{C}_{16: 0}$ & $\operatorname{tr}$ & 1.2 & 1.0 & 1.0 & 1.1 & & & 2.6 \\
\hline $\mathrm{C}_{16: 0} 3-\mathrm{OH}$ & $\operatorname{tr}$ & 1.7 & $\operatorname{tr}$ & & & 1.3 & & 2.3 \\
\hline iso- $\mathrm{C}_{16: 0}$ & $\operatorname{tr}$ & 18.8 & 8.5 & 1.0 & 8.7 & 16.6 & 5.2 & 7.2 \\
\hline iso- $\mathrm{C}_{16: 0} 3-\mathrm{OH}$ & $\operatorname{tr}$ & 12.6 & 16.5 & $\operatorname{tr}$ & 7.4 & 5.0 & 3.6 & 10.4 \\
\hline iso- $\mathrm{C}_{16: 1}$ & & 4.0 & 2.9 & & 4.1 & 3.0 & 2.2 & 2.9 \\
\hline $\mathrm{C}_{17: 0} 3-\mathrm{OH}$ & $\operatorname{tr}$ & & $\operatorname{tr}$ & $\operatorname{tr}$ & & 1.5 & & 1.1 \\
\hline iso- $\mathrm{C}_{17: 0} 3-\mathrm{OH}$ & 7.6 & 5.3 & 2.7 & 17.7 & 6.6 & 10.3 & 16.0 & 6.5 \\
\hline $\mathrm{C}_{17: 1} \omega 6 c$ & $\operatorname{tr}$ & & & & & & & 2.5 \\
\hline $\mathrm{C}_{17: 1} \omega 8 c$ & $\operatorname{tr}$ & & & & & & & 1.3 \\
\hline iso- $\mathrm{C}_{17: 1} \omega 9 c$ & 15.5 & 1.5 & & 7.5 & 3.7 & 6.2 & 11.7 & 1.5 \\
\hline $\mathrm{C}_{18: 1} \omega 5 c$ & 1.5 & & & $\operatorname{tr}$ & & & & \\
\hline Summed feature $3^{\star}$ & 2.5 & 2.0 & 3.6 & 9.8 & & 1.3 & 2.4 & 7.0 \\
\hline
\end{tabular}

${ }^{*}$ Summed features are combinations of fatty acids that cannot be separated by the MIDI system. Summed feature 3 comprises iso- $\mathrm{C}_{15: 0} 2$-OH and/ or $\mathrm{C}_{16: 1} \omega 7 c$. 
of the isolate was $40.6 \mathrm{~mol} \%$, within the range of 30 $42 \mathrm{~mol} \%$ reported in the genus Flavobacterium (Bernardet \& Bowman, 2006).

Genomic relatedness between the isolate and its most closely related phylogenetic neighbour $F$. cucumis R2A45$3^{\mathrm{T}}$ (obtained from Dr Soon-Wo Kwon, KACC, Suwon, Korea) was determined by DNA-DNA hybridization, which was carried out spectrophotometrically (De Ley, 1970). The hybridization value was $5.4 \%$, indicating that the isolate represents a different species from F. cucumis R2A $45-3^{\mathrm{T}}$.

The results of a polyphasic taxonomy study support the description of strain NJ-26 ${ }^{\mathrm{T}}$ as a representative of a novel species of the genus Flavobacterium, for which the name Flavobacterium cheniae sp. nov. is proposed.

\section{Description of Flavobacterium cheniae sp. nov.}

Flavobacterium cheniae (che' ni.ae. N.L. fem. gen. n. cheniae of Chen, named in honour of Professor Wen-Xin Chen, for her contribution to environmental microbiology).

Cells are aerobic, Gram-negative, rods, $0.3-0.5 \mu \mathrm{m}$ in diameter and 1.5-3.0 $\mu \mathrm{m}$ long, motile by gliding. Colonies on R2A agar incubated at $28{ }^{\circ} \mathrm{C}$ for 2 days are yellow, circular, about $1 \mathrm{~mm}$ in diameter and non-spreading. Growth occurs at $18-32{ }^{\circ} \mathrm{C}$ (optimum, $28{ }^{\circ} \mathrm{C}$ ), at $\mathrm{pH}$ 6.5-8.0 (optimum, 7.5) and with $0-0.8 \% \mathrm{NaCl}$ (optimum growth in the absence of $\mathrm{NaCl}$ ). Growth occurs on NA and TSA (weakly), but not on MA or PYG agar. Oxidase- and catalase-positive. Flexirubintype pigments are absent. $\mathrm{H}_{2} \mathrm{~S}$ is produced weakly. Nitrate is not reduced. ONPG is not hydrolysed. Gelatin is degraded strongly, but pectin, chitin, Tween 80, CM-cellulose, casein, DNA and urea are not. Tyrosine is degraded and a brown pigment is produced on tyrosine agar. Alkaline phosphatase and weak lipase activities are present, but $\beta$-galactosidase, urease, tryptophan deaminase and arginine dihydrolase activities are absent. Does not assimilate any of the carbohydrates tested, including raffinose, salicin, lactose, melezitose, D-mannose, trehalose, melibiose, glucose, sucrose, maltose, mannitol, D-galactose, L-rhamnose, D-xylose, Dsorbose, D-sorbitol, D-fructose, inulin, D-arabinose, L-arabinose, D-ribose, inositol, citrate, sorbic acid, succinate, glycerol and aspartic acid. The major cellular fatty acids $(>5 \%)$ of the type strain are iso- $\mathrm{C}_{15: 0}(27.7 \%)$, iso- $\mathrm{C}_{17: 1} \omega 9 c(15.5 \%)$, $\mathrm{C}_{15: 0}(15.4 \%)$, iso- $\mathrm{C}_{17: 0} 3-\mathrm{OH}(7.6 \%)$, iso- $\mathrm{C}_{15: 1} \mathrm{G}(7.2 \%)$ and iso- $\mathrm{C}_{15: 0} 3-\mathrm{OH}(6.3 \%)$. The DNA G $+\mathrm{C}$ content of the type strain is $40.6 \mathrm{~mol} \%$.

The type strain is $\mathrm{NJ}-26^{\mathrm{T}}\left(=\mathrm{CGMCC} 1.6844^{\mathrm{T}}=\mathrm{NBRC}\right.$ $103934^{\mathrm{T}}$ ), isolated from sediment of Guanting Reservoir in Beijing, China.

\section{Acknowledgements}

We are thankful to Dr Soon-Wo Kwon for the kind donation of the type strain Flavobacterium cucumis $\mathrm{R} 2 \mathrm{~A} 45-3^{\mathrm{T}}$. This work was supported by a project (no. 30670071) from the Chinese National Natural Science Foundation, the Hi-tech Research and Development
Program (863 Program) of China (No. 2006AA10A213) and the Taihu Project (no. BK2007741) from Jiangsu Science and Technology Department. We are indebted to the Associate Editor for his kind help in modification of the manuscript.

\section{References}

Bergey, D. H., Harrison, F. C., Breed, R. S., Hammer, B. W. \& Huntoon, F. M. (editors) (1923). Bergey's Manual of Determinative Bacteriology. Baltimore: Williams \& Wilkins.

Bernardet, J.-F. \& Bowman, J. (2006). The genus Flavobacterium. In The Prokaryotes: a Handbook on the Biology of Bacteria, 3rd edn, vol. 7, pp. 481-531. Edited by M. Dworkin, S. Falkow, E. Rosenberg, K. H. Schleifer \& E. Stackebrandt. New York: Springer.

Bernardet, J.-F. \& Grimont, P. A. D. (1989). Deoxyribonucleic acid relatedness and phenotypic characterization of Flexibacter columnaris sp. nov., nom. rev., Flexibacter psychrophilus sp. nov., nom. rev. and Flexibacter maritimus. Int J Syst Bacteriol 39, 346-354.

Bernardet, J.-F., Segers, P., Vancanneyt, M., Berthe, F., Kersters, K. \& Vandamme, P. (1996). Cutting a Gordian knot: emended classification and description of the genus Flavobacterium, emended description of the family Flavobacteriaceae, and proposal of Flavobacterium hydatis nom. nov. (basonym, Cytophaga aquatilis Strohl and Tait 1978). Int J Syst Bacteriol 46, 128-148.

Bernardet, J.-F., Nakagawa, Y. \& Holmes, B. (2002). Proposed minimal standards for describing new taxa of the family Flavobacteriaceae and emended description of the family. Int J Syst Evol Microbiol 52, 1049-1070.

Chun, J., Lee, J.-H., Jung, Y., Kim, M., Kim, S., Kim, B. K. \& Lim, Y. W. (2007). EzTaxon: a web-based tool for the identification of prokaryotes based on $16 \mathrm{~S}$ ribosomal RNA gene sequences. Int J Syst Evol Microbiol 57, 2259-2261.

Cousin, S., Päuker, O. \& Stackebrandt, E. (2007). Flavobacterium aquidurense sp. nov. and Flavobacterium hercynium sp. nov., from a hard-water creek. Int J Syst Evol Microbiol 57, 243-249.

De Ley, J. (1970). Reexamination of the association between melting point, buoyant density, and chemical base composition of deoxyribonucleic acid. J Bacteriol 101, 737-754.

Dong, X.-Z. \& Cai, M.-Y. (2001). Determinative Manual for Routine Bacteriology. Beijing: Scientific Press.

Johnson, J. L. (1985a). Determination of DNA base composition. Methods Microbiol 18, 1-31.

Johnson, J. L. (1985b). DNA reassociation and RNA hybridisation of bacterial nucleic acids. Methods Microbiol 18, 33-74.

Kim, B.-Y., Weon, H.-Y., Cousin, S., Yoo, S.-H., Kwon, S.-W., Go, S.-J. \& Stackebrandt, E. (2006). Flavobacterium daejeonense sp. nov. and Flavobacterium suncheonense sp. nov., isolated from greenhouse soil in Korea. Int J Syst Evol Microbiol 56, 1645-1649.

Kumar, S., Tamura, K. \& Nei, M. (2004). MEGA3: integrated software for molecular evolutionary genetics analysis and sequence alignment. Brief Bioinform 5, 150-163.

Marmur, J. (1961). A procedure for the isolation of deoxyribonucleic acid from microorganisms. J Mol Biol 3, 208-218.

Park, M., Lu, S., Ryu, S. H., Chung, B. S., Park, W., Kim, C. J. \& Jeon, C. O. (2006). Flavobacterium croceum sp. nov., isolated from activated sludge. Int J Syst Evol Microbiol 56, 2443-2447.

Park, M., Ryu, S. H., Vu, T.-H. T., Ro, H.-S., Yun, P.-Y. \& Jeon, C. O. (2007). Flavobacterium defluvii sp. nov., isolated from activated sludge. Int J Syst Evol Microbiol 57, 233-237.

Thompson, J. D., Higgins, D. G. \& Gibson, T. J. (1994). CLUSTAL W: improving the sensitivity of progressive multiple sequence alignment 
through sequence weighting, position-specific gap penalties and weight matrix choice. Nucleic Acids Res 22, 4673-4680.

Weon, H.-Y., Song, M.-H., Son, J.-A., Kim, B.-Y., Kwon, S. W., Go, S.-J. \& Stackebrandt, E. (2007). Flavobacterium terrae sp. nov. and Flavobacterium cucumis sp. nov., isolated from greenhouse soil. Int $J$ Syst Evol Microbiol 57, 1594-1598.

Ying, J.-Y., Liu, Z.-P., Wang, B.-J., Dai, X., Yang, S.-S. \& Liu, S.-J.

(2007). Salegentibacter catena sp. nov., isolated from sediment of the
South China Sea, and emended description of the genus Salegentibacter. Int J Syst Evol Microbiol 57, 219-222.

Yoon, J.-H., Kang, S.-J., Lee, J.-S. \& Oh, T.-K. (2007). Flavobacterium terrigena sp. nov., isolated from soil. Int J Syst Evol Microbiol 57, 947-950.

Zhu, F., Wang, S. \& Zhou, P.-J. (2003). Flavobacterium xinjiangense sp. nov. and Flavobacterium omnivorum sp. nov., novel psychrophiles from the China No. 1 glacier. Int J Syst Evol Microbiol 53, 853-857. 